\title{
LITERATURE REVIEW: INTERVENSI SHORT WAVE DIATHERMY DAN LATIHAN CALISTHENIC UNTUK MENINGKATKAN KEMAMPUAN FUNGSIONAL DAN KESEIMBANGAN PADA KASUS OSTEOARTHRITIS LUTUT KRONIS
}

\author{
Iqbal Ismail ${ }^{1}$, Heri Wibisono ${ }^{2}$ \\ 1,2Program Studi Fisioterapi Program Diploma Tiga, Fakultas Ilmu Kesehatan \\ Universitas Pembangunan Nasional Veteran Jakarta, Indonesia \\ *Email korespondesi: heri.wibisono@upnvj.ac.id
}

\begin{abstract}
ABSTRAK
Untuk mempelajari dan memeriksa bukti tentang efek yang dihasilkan dari short wave diathermy dan latihan calisthenic dalam meningkatkan kemampuan fungsional dan keseimbangan pada penderita osteoarthritis lutut kronik. Penelitian ini menggunakan metode literature review dengan pencarian sumber data yang telah diterbitkan setelah atau terakhir tahun 2015 melalui Google Schoolar, Science Direct, PubMed menggunakan kata kunci seperti osteoarthritis, calisthenic, kemampuan fungsional, keseimbangan, dan fisioterapi. Untuk menilai kualitas jurnal ataupun artikel yang telah terpilih menggunakan Scimago Journal \& Country Rank (SJR). Analisis data literatur dilakukan berdasarkan kesesuaian bahasan, metode penelitian, sampel penelitian, dan pengukuran hasil/parameter yang digunakan. Setelah dilakukan analisa, didapati 6 jurnal yang sesuai kriteria inklusi. Hasilnya adalah latihan calisthenic secara signifikan dapat meningkatkan kemampuan fungsional dan keseimbangan. Untuk intervensi SWD juga dapat meningkatkan kemampuan fungsional pada penderita osteoarthritis lutut. Sulit menemukan literatur yang membahas mengenai dampak short wave diathermy terhadap keseimbangan. Latihan calisthenic mampu meningkatkan kemampuan fungsional dan keseimbangan pada penderita osteoarthritis lutut kronis. Sedangkan short wave diathermy hanya mampu meningkatkan kemampuan fungsional.
\end{abstract}

Kata Kunci: osteoarthritis, calisthenic, kemampuan fungsional, keseimbangan, fisioterapi

\begin{abstract}
To study and examine the evidence regarding the effects of short wave diathermy and calisthenic exercises in improving functional ability and balance in patients with chronic knee osteoarthritis. This study using the literature review method by searching data sources that have been published after or last year 2015 through Google Schoolar, Science Direct, PubMed using keywords such as osteoarthritis, calisthenic, functional abilities, balance, and physiotherapy. To assess the quality of selected journals or articles, using the Scimago Journal \& Country Rank (SJR). Analysis was performed based on the suitability of the discussion, research methods, samples, and outcome measurement/parameters used. After analyzing, 6 journals met the inclusion criteria. The result was that calisthenic exercises can significantly improve functional abilities and balance. Short wave diathermy interventions can also improve functional abilities in patients with osteoarthritis of the knee. It was difficult to find literature that discusses the impact of short wave diathermy on balance. Calisthenic exercises can improve functional ability and balance in patients with chronic knee osteoarthritis. Whereas the short wave diathermy is only able to improve functional abilities.
\end{abstract}

Keywords: osteoarthritis, calisthenic, functional ability, balance, physiotherapy 


\section{PENDAHULUAN}

Osteoarthritis (OA) adalah penyakit penuaan/degeneratif akibat dari pemecahan biokimia artikular (hialine) tulang rawan pada sendi lutut yang termasuk sendi sinovial sehingga tulang rawan tersebut mengalami kerusakan. OA memiliki perkembangan yang lambat, tidak beraturan dan tidak peradangan, yang ditandai dengan munculnya perubahan bantalan sandi dan terbentuknya osteofit pada sisi-sisi sendi (Marlina, 2015).

Seperti yang telah disampaikan sebelumnya, osteoarthritis merupakan suatu peradangan sendi yang disebabkan karena faktor degeneratif atau penuaan. Berdasarkan data penduduk yang diambil ketika tahun 2017 terdapat $\pm 23,66$ juta penduduk lanjut usia di Indonesia $(9,03 \%)$. Diperkirakan total penduduk berusia lanjut pada tahun 2020 sekitar 27,08 juta jiwa, lalu melonjak setiap tahunnya yaitu pada tahun 2025 (33,69 juta), tahun 2030 (40,95 juta) dan pada tahun 2035 menjadi 48,19 juta jiwa penduduk lanjut usia, naik sekitar 4-7 juta jiwa per tahunnya (Kemenkes Republik Indonesia, 2017). Dengan hal tersebut mendasari penulis untuk mengambil penelitian tentang osteoarthritis, karena semakin meningkatnya jumlah penduduk lansia setiap tahunnya yang kemungkinan besar akan menderita osteoarthritis.

OA lutut dan panggul memiliki prevalensi yang lebih tinggi dibandingkan dengan sendi lainnya, penyebabnya adalah karena kedua sendi tersebut memiliki tugas yang lebih berat yaitu sebagai sendi penumpu berat badan. Adapun penelitian mengenai prevalensi OA lutut dan panggul terhadap 7.577 sampel di Amerika, mengatakan bahwa prevalensi OA panggul sekitar 7,4\% kejadiannya pada laki-laki $(6,7 \%)$ lebih rendah dibandingkan perempuan $(8 \%)$. Sedangkan pada OA lutut memiliki prevalensi sekitar $12,2 \%$, dengan perbandingan laki-laki $(8,7 \%)$ pada perempuan $(14,9 \%)$ dengan peningkatan usia.

Hal ini menunjukkan kembali bahwa wanita memiliki prevalensi yang lebih tinggi untuk OA lutut dibanding laki-laki. Dari pernyataan diatas bisa diambil kesimpulan bahwa presentase prevalensi OA panggul lebih rendah dibandingkan dengan OA lutut. Di Indonesiasendiri prevalensi terjadinya osteoarthritis mencapai 5\% pada kisaran usia dibawah 40 tahun, mengalami peningkatan yang signifikan pada usia 40-60 tahun yaitu sekitar 30\%, lalu melonjak drastis pada usia 61 tahun ke atas yaitu sekitar 65\% (Marlina, 2015).

Short wave diathermy atau biasa disingkat dengan SWD merupakan salah satu modalitas atau alat yang sudah umum digunakan sebagai bentuk intervensi untuk menangani berbagai kasus di dunia kesehatan, terutama fisioterapi. SWD adalah alat dengan gelombang elektromagnetik yang mampu menghasilkan frekuensi tinggi (10-100 MHz). Namun penggunaan untuk kesehatan biasanya menggunakan frekuensi $27,12 \mathrm{MHz}$ dengan panjang gelombang bisa mencapai $11 \mathrm{~m}$, serta memiliki dua mode yaitu mode pulsed dan mode continuous (Knight \& Draper, 2008).

Salah satu bentuk intervensi untuk mengurangi gejala yang ditimbulkan dari OA adalah latihan calisthenic. Latihan ini terdiri dari beberapa kontraksi otot pendek yang memiliki gerakan berirama yang berfungsi untuk meningkatkan kelenturan serta kekuatan otototot tubuh dengan menggunakan berat badan individu masing-masing (Gurudut, Welling, \& Naik, 2018).

\section{METODE}

Metode yang digunakan dalam penulisan artikel ini adalah literature review, yaituebuah pencarian literatur baik internasional maupun nasional yang dilakukan dengan menggunakan database seperti Google Schoolar, Science Direct, PubMed, dan lain-lain. Menentukan kriteria inklusi yaitu; sesuai dengan judul dan tema yang diambil dalam studi literatur ini, artikel yang dipublikasi secara nasional dan internasional, artikel yang diterbitkan minimal 5 tahun terakhir, dan bukan termasuk jurnal predator. Serta kriteria eksklusi yaitu; Artikel yang diterbitkan sebelum tahun 2015 dan artikel yang tidak lolos Scimago Journal \& Country Rank (SJR). 
Setelah semua data literatur terkumpul dan lengkap maka akan dilakukan langkah-langkah analisa data dengan cara menggunakan analisis kualitatif yaitu dengan cara menganalisis makna-makna yang di dapat akan atau terkandung dalam sumber data yang di peroleh, isi yang sesuai dengan pokok bahasan yang ada dalam rumusan masalah, kemudian di golongkan dan di identifikasi. Kemudian menjelaskan hasil data yang di peroleh berdasarkan sumber data yang didapatkan sesuai dengan ketentuan-ketentuan, sehingga dapat disimpulkan dari sumber data yang telah didapatkan.

\section{PEMBAHASAN}

Dalam studi literatur ini, penulis melakukan literatur review terhadap artikel ilmiah yang telah terpublikasi lalu dipilih dan diseleksi sesuai dengan kriteria inklusi dan eksklusi yang telah ditentukan sebelumnya. Tujuannya yaitu untuk mengetahui efek dari short wave diathermy dan latihan calisthenic dalam meningkatkan kemampuan fungsional dan keseimbangan pada penderita osteoarthritis lutut. Setelah dilakukan analisa data literatur dan evaluasi terhadap jurnaljurnal yang telah didapatkan, maka penulis telah menentukan 6 literatur berupa jurnal untuk dijadikan sumber data dalam studi literatur ini. Jurnal-jurnal tersebut tentunya sesuai dengan karakteristik dan kriteria yang penulis butuhkan. Studi literatur ini dilakukan mulai dari bulan April sampai dengan bulan Juni 2020.

\section{Short Wave Diathermy Terhadap Osteoarthritis Lutut}

Pada studi literatur ini terdapat 2 jurnal terpilih yang membahas tentang efek short wave diathermy pada penderita osteoarthritis lutut. Dari 2 jurnal tersebut penulis telah menganalisa dan merangkum efek dari short wave diathermy terhadap osteoarthritis lutut. Pada jurnal penelitian yang dilakukan oleh (Fukuda et al., 2016) menggunakan alat SWD dengan mode pulsed berfrekuensi 27,12 MHz, daya puncak mencapai $250 \mathrm{~W}$, dan durasi pulse mencapai 400 mikro detik. Untuk penggunaan ke pasien, menggunakan frekuensi sebesar $145 \mathrm{~Hz}$, yang menghasilkan daya rata-rata $14,5 \mathrm{~W}$. Penelitian ini dibagi menjadi 2 grup, grup pertama pSWD (pulsed Short Wave Diathermy) dengan dosis rendah yaitu durasinya 19 menit per sesi dengan sekitar $17 \mathrm{~kJ}$ dari total energi. Sedangkan grup kedua pSWD dengan dosis tinggi, mendapatkan waktu 38 menit per sesi dengan total energi $33 \mathrm{~kJ}$. Kedua grup diberikan $3 \mathrm{kali}$ sesi dalam seminggu, dengan total waktu selama 3 minggu. Hasilnya menunjukkan terdapat peningkatan pada kemampuan fungsional di kedua grup. Dan terdapat fakta bahwa pSWD dengan dosis rendah menunjukkan hasil yang lebih efektif untuk jangka panjang.

Selanjutnya terdapat penelitian yang membahas hal serupa (Ozen, Doganci, Ozyuvali, \& Yalcin, 2019) dengan penelitian diatas, yaitu membahas mengenai short wave diathermy. Penanganannya dilakukan selama 5 hari berturut-turut per minggu dalam total jangka waktu hingga 3 minggu, dengan waktu 15 menit dalam satu sesinya dan menggunakan frekuensi 27,12 MHz. Namun terdapat perbedaan metode yaitu dengan adanya pembagian grup dalam penelitian ini untuk membandingkan efek yang dihasilkan satu sama lain. Dimana grup 1 menggunakan mode continuous (cSWD) dan grup 2 menggunakan mode pulsed (pSWD). Hasilnya menunjukkan bahwa ada penurunan yang sangat signifikan secara klinis dalam total penilaian WOMAC setelah dilakukan penanganan. Dimana perubahan total skor WOMAC grup cSWD adalah 26\% dan grup pSWD 23\%. Namun untuk penilaian 6MWT (6 Minute Walking Test) tidak menunjukkan perubahan klinis yang penting di kedua grup.

\section{Latihan Calisthenic Terhadap Osteoarthritis Lutut}

Pada studi literatur ini terdapat 4 jurnal terpilih yang membahas tentang efek latihan calisthenic maupun latihan lainnya pada penderita osteoarthritis lutut. Dari 4 jurnal tersebut penulis telah menganalisa dan akan menjabarkannya dengan seksama. Pada penelitian yang dilakukan oleh (Anwer, Alghadir, \& Brismeé, 2016) yang membahas 
tentang berbagai latihan yang dapat dilakukan dirumah bagi penderita OA lutut. Diantaranya adalah open and close kinematic chain exercise, muscle stretching, ROM exercise, dan balance exercise. Setelah melakukan latihan-latihan tersebut didapati hasil yang signifikan dalam peningkatankemampuan fungsional menggunakan parameter WOMAC. Walaupun latihan calisthenic berbeda dengan latihan-latihan yang digunakan dalam penelitian ini, namun semua latihan tersebut memiliki manfaat dan dampak yang positif. Hal lainnya mengenai masalah perbedaan ini akan dibahas di poin selanjutnya.

Jurnal yang akan dibahas selanjutnya yaitu sebuah penelitian yang dilakukan oleh (Gurudut et al., 2018) membahas tentang latihan calisthenic untuk penderita OA lutut. Subjek dari penelitian ini diberikan berbagai latihan calisthenic dengan intensitas yang rendah sebanyak 10 sesi selama 10 hari dengan durasi per sesinya selama 10 menit, dengan 10 kali repetisi untuk setiap gerakan tanpa adanya waktu rest. Setelah dilakukan evaluasi pada hari ke 10 secara statistik menunjukkan hasil yang signifikan terhadap skor kemampuan fungsional lutut serta penilaian keseimbangan yang mengalami peningkatan.

Menurut (Braghin, Libardi, Junqueira, Nogueira - Barbosa, \& de Abreu, 2018) dalam penelitiannya yang menggunakan metode RCT, serta berisi kelompok-kelompok yang dibagi menjadi 3. Kelompok 1 diisi oleh pasien dengan gejala OA lutut, kelompok 2 diisi pasien yang tidak mengalami gejala OA lutut, serta kelompok 3 yang diisi campuran antara pasien yang mengalami dan tidak mengalami gejala OA lutut namun tidak diberikan intervensi. Pada kelompok 1 dan 2 diberikan latihan fisik selama dua kali seminggu dalam total waktu 8 minggu, dengan durasi latihan yaitu sekitar 50-60 menit. Periode latihan ini dipilih karena penelitian sebelumnya yang dilakukan oleh (Reis, Costa, Schmidt, Ferreira, \& Abreu, 2012) menunjukkan bahwa waktu 8 minggu sudah cukup untuk penguatan otot dan meningkatkan fungsi. Setelah dilakukan evaluasi pada minggu terakhir, ditemukan hasil secara signifikan pada kelompok 1 yang mengalami penurunan nilai parameter WOMAC pada kemampuan fungsional. Hal ini dapat diartikan bahwa terdapat peningkatan kemampuan fungsional setelah dilakukan latihan pada penderita OA lutut. Sedangkan pada penilaian Step Up/Over tes, kelompok 2 mengalami penurunan hasil catatan waktu yang diraih setelah melakukan intervensi selama 8 minggu. Artinya bahwa keseimbangan pada penderita OA menunjukkan peningkatan yang signifikan setelah melakukan prosedur latihan yang diberikan.

Selanjutnya penelitian yang dilakukan oleh (Kuru Çolak et al., 2017) mendapatkan 56 pasien dengan OA lutut. Dari pasien tersebut dibagi menjadi 2 grup, grup yang diawasi (1) dan grup dengan program latihan berbasis rumahan (2). Grup pertama melakukan latihan diklinik yang diawasi langsung oleh fisioterapis, lalu grup kedua menerapkan program latihan yang telah diberikan dan dilakukan dirumah masingmasing tanpa adanya pengawasan. Hasilnya adalah terdapat peningkatan pada kedua grup yang signifikan dalam kemampuan fungsional yang diketahui melalui penilaian tes 6 Minute Walking. Lalu untuk penilaian keseimbangan, grup yang diawasi menunjukkan peningkatan yang signifikan.

\section{KESIMPULAN}

Sesuai dengan hasil analisa dan pembahasan yang telah dilakukan dapat disimpulkan bahwa latihan calisthenic mampu meningkatkan kemampuan fungsional dan keseimbangan pada penderita osteoarthritis lutut. Untuk intervensi short wave diathermy juga dapat meningkatkan kemampuan fungsional pada penderita osteoarthritis lutut. Namun sulit menemukan literatur yang membahas mengenai dampak short wave diathermy terhadap keseimbangan.

\section{DAFTAR PUSTAKA}

Anwer, S., Alghadir, A., \& Brismeé, J. M. (2016). Effect of Home Exercise Program in Patients with Knee Osteoarthritis: A 
Systematic Review and Meta-analysis. Journal of Geriatric Physical Therapy, 39(1), $38-48$. https://doi.org/10.1519/JPT.00000000000 00045

Braghin, R. de M. B., Libardi, E. C., Junqueira, C., Nogueira - Barbosa, M. H., \& de Abreu, D. C. C. (2018). Exercise on balance and function for knee osteoarthritis: A randomized controlled trial. Journal of Bodywork and Movement Therapies, 22(1), 76-82. https://doi.org/10.1016/j.jbmt.2017.04.00 6

Fukuda, T. Y., Alves da Cunha, R., Fukuda, V. O., Rienzo, F. A., Cazarini, C., Carvalho, N. de A. A., \& Centini, A. A. (2016). Pulsed Shortwave Treatment in Women With Knee Osteoarthritis: A Multicenter, Randomized, PlaceboControlled Clinical Trial. Physical Therapy, 91(7), 1009-1017. https://doi.org/10.2522/ptj.20100306

Gurudut, P., Welling, A. A., \& Naik, R. (2018). Comparative Effect of Calisthenic and Proprioceptive Exercises on Pain, Proprioception, Balance and Function in Chronic Osteoarthritis of Knee. Journal of Exercise Science and Physiotherapy, 14(2), 50-61. https://doi.org/10.18376/jesp/2018/v14/i2 $/ 111310$

Kemenkes Republik Indonesia. (2017). Situasi lansia di Indonesia tahun 2017: Gambar struktur umur penduduk insonesia tahun 2017. Pusat Data Dan Informasi, 1--9.

Knight, L. K., \& Draper, O. D. (2008). Therapeutic Modalities: The Art and Science (E. Lupash, M. Brittain, \& J. Montalbano, eds.). Philadelphia:
Lippincott Williams and Wilkins.

Kuru Çolak, T., Kavlak, B., Aydoğdu, O., Şahin, E., Acar, G., Demirbüken, İ., ... Polat, M. G. (2017). The effects of therapeutic exercises on pain, muscle strength, functional capacity, balance and hemodynamic parameters in knee osteoarthritis patients: a randomized controlled study of supervised versus home exercises. Rheumatology International, 37(3), 399-407. https://doi.org/10.1007/s00296-016-36465

Marlina, T. (2015). Efektivitas latihan lutut terhadap penurunan intensitas nyeri pasien osteoarthritis lutut di yogyakarta. Jurnal Keperawatan Sriwijaya, 2(2355), 44-56.

Ozen, S., Doganci, E. B., Ozyuvali, A., \& Yalcin, A. P. (2019). Effectiveness of continuous versus pulsed short-wave diathermy in the management of knee osteoarthritis: A randomized pilot study. Caspian Journal of Internal Medicine, 10(4), 431-438. https://doi.org/10.22088/cjim.10.4.41

Reis, J. G., Costa, G. C., Schmidt, A., Ferreira, C. H. J., \& Abreu, D. C. C. (2012). Do muscle strengthening exercises improve performance in the 6-minute walk test in postmenopausal women? | O exercício de força muscular é eficiente para melhorar o desempenho no teste de caminhada de 6 minutos em mulheres pós-menopausais? Brazilian Journal of Physical Therapy, 16(June), 3-7. https://doi.org/10.1590/S141335552012005000022 